\title{
SERVICE IMPLEMENTATION OF CONSUMER INTEREST IN TEBING TINGGI BUSINESS CLINIC SUMATERA UTARA
}

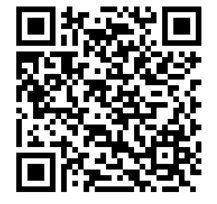

\author{
M. Umar Maya Putra ${ }^{* 1}$, Syafrida Damanik ${ }^{2}$ \\ ${ }^{* 1}$ Economic Faculty, Universitas Al-Azhar, Indonesia \\ 2 Engineering Faculty, Universitas Al-Azhar, Indonesia
}

DOI: https://doi.org/10.29121/granthaalayah.v8.i9.2020.1387

Article Type: Research Article

Article Citation: M. Umar Maya Putra, and Syafrida Damanik. (2020). SERVICE

IMPLEMENTATION OF CONSUMER INTEREST IN TEBING TINGGI BUSINESS CLINIC SUMATERA

UTARA. International Journal of

Research -GRANTHAALAYAH, 8(9), 200-208.

https://doi.org/10.29121/granthaa

layah.v8.i9.2020.1387

Received Date: 02 September 2020

Accepted Date: 30 September 2020

Keywords:

Consumer

Entreprises

Busines

Tebing Tinggi

\section{ABSTRACT}

This research begins with the development of MSMEs (Micro, Small and Medium Enterprises) which is an illustration of strengthening regional potential. Developing MSMEs can improve services to consumers in order to create buying interest. The benchmarks that are assessed through the level of confidence in a product directly aim to analyze customer interest. In this study, it is explained that customer interest is product quality, service quality, price, and cost which are closely related to meeting the service needs of the Tebing Tinggi Business Clinic (KLIBI) assisted them. The method used is the canonical analysis method which is a multivariate model that studies the relationship between the dependent variable set varied from the independent variable set. The data characteristics for canonical correlation are metric data, namely interval or ratio data. The research result gained that responsiveness and concern give the significant effect on the cost so that customers want to buy continuously. For the recommendation, The Government needs to improve the quality of product endorsement among Tebing Tinggi and Indonesian consumers by making the program business promotion and international exhibitions through KLIBI.

\section{INTRODUCTION}

The current rapid development of MSMEs can be used as a potential for an area to become stronger in terms of strengthening the supply of goods and services. It makes them think about patterns of service to consumers in order to increase their buying interest continuously

The power of product sales can increase consumer interest. The choices and product offerings provided, present quality products and convince consumers' interest [1].

Customer interest can be measured from four dimensions such as product quality, service quality, price and cost. This can be used as a benchmark where the level of confidence in a product can be measured directly [2].

Tebing Tinggi City is an area that has 53.32\% land allocated for settlements, followed by agriculture (29.66\%). This area also has considerable potential in other sectors such as agriculture, mining, industry and trade to strengthen buying interest and improve services. The development of trade needs to be strengthened in order to improve the welfare of society, especially in improving the quality of entrepreneurs in getting as many consumers as possible [3].

(C) 2020 The Author(s). This is an open access article distributed under the terms of the Creative Commons Attribution License, which permits unrestricted use, distribution, and reproduction in any medium, provided the original author and source are credited. 
Researchers are interested in taking several indicators that researchers think affect the fulfillment of their service needs assisted by KLIBI Tebing Tinggi, It gets customers who are always committed to improving creativy and innovative product who have promoted at home and abroad, so it had been to review the implementation of consumer Interest in services of the Tebing Tinggi Business Clinic Foster Partners through Canonical Correlation The development of the rapid trade sector in Tebing Tinggi City

Based on the background that has been described, the research problems can be described how to implement customer interest (product quality, service quality, price, and costs) in meeting service needs, how to measure the canonical correlation between customer interest and the dimensions of meeting service needs and recommendations for what to do. to improve the analysis of customer interest for SMEs assisted by Klibi Tebing Tinggi.

\section{MATERIALS AND METHODS}

\subsection{PRODUCT QUALITY}

Product quality has the value in the target market where its ability to provide benefits and satisfaction, including things, services, organizations, places, people, and ideas [4].

Small businesses can get into problems in improving product quality because of the minimal role of society as subjects in development and still not at the level of welfare so it is very difficult to develop creativity and innovation [5].

\subsection{QUALITY OF SERVICE}

Identification of human capital, can be seen with the actors or stakeholders involved and assess their interests in the system in improving the quality of services produced to identify parties directly, classify related parties based on interests, comply with related party regulations in the use of economic resources local area [6].

Service quality is a customer long-term cognitive evaluation of the delivery of a company's services which has five dimensions, among others : Direct Evidence (Tangibles), Reliability (Reliability) the company's ability to provide services as promised accurately and reliably, Responsiveness is a policy to help and provide fast (responsive) and appropriate service to customers by delivering clear information Assurance is knowledge of politeness, and the ability of company employees to foster a sense of trust from customers in the company. It is a sincere and individualized or personal attention given to customers by trying to understand consumer desires [2].

\subsection{PRICE}

Price sometimes refers to the quantity of payment demanded by sellers of goods or services, not the amount that is ultimately paid. This quantity demanded is often called the asking or selling price, whereas the actual payment may be called the transaction price or traded price [7].

Prices are all forms of monetary costs sacrificed by consumers to obtain, own, utilize a number of combinations of goods and services from a product [8].

\subsection{COST}

Production costs determine the amount of the selling price of a product or service which will later affect the amount of profit earned. As stated by Mulyadi in his book cost accounting, states that production costs affect operating profits [9].

The application of standard costs can encourage company executives and supervisors to increase the efficiency and effectiveness of the production process to achieve predetermined standards. Standard costing can provide guidelines for knowing the costs that should have occurred in the production process [10]. 


\subsection{RESPONSIVENESS}

Service responsiveness provides the ability to service accurately and the ability to be trusted (dependably on time (on time) without making the slightest mistake [11].

The purpose of raw material inventory is to guarantee responsively to ensure the availability of raw materials at an optimal level so that the production process can run according to plan at minimum cost levels [2].

\subsection{CONCERN}

With the correct purpose of a business being done, it will increase enthusiasm or increase awareness in directing behavior to achieve goals, both personal and organizational [12].

Reformers and government agencies play a role in changing the face of the local landscape in an area in order to improve the socio-economic quality that can improve the economy of a region. With concern in delivering information obtained programmatically, socio-economic mapping has been programmed to provide solutions in improving the community's economy [13].

In business development, Micro and Small Enterprises (MSEs) can become crackers or what are commonly called reformers. At the beginning of the 21st century, Indonesia was marked by traditional businesses that were timeless and still needed change and concern in serving consumers [14].

\subsection{CONCEPTUAL FRAMEWORK}

From the literature review and previous research, 6 determinants of elements of consumer interest in the services of the Tebing Tinggi Business Clinic foster partners were derived, namely Product Quality $\left(\mathrm{X}_{1}\right)$, Service Quality $\left(\mathrm{X}_{2}\right)$, Price $\left(\mathrm{X}_{3}\right)$ and Cost $\left(\mathrm{X}_{4}\right)$, which were identified with Service, namely Responsiveness. $\left(\mathrm{Y}_{1}\right)$ and Concern $\left(\mathrm{Y}_{2}\right)$.

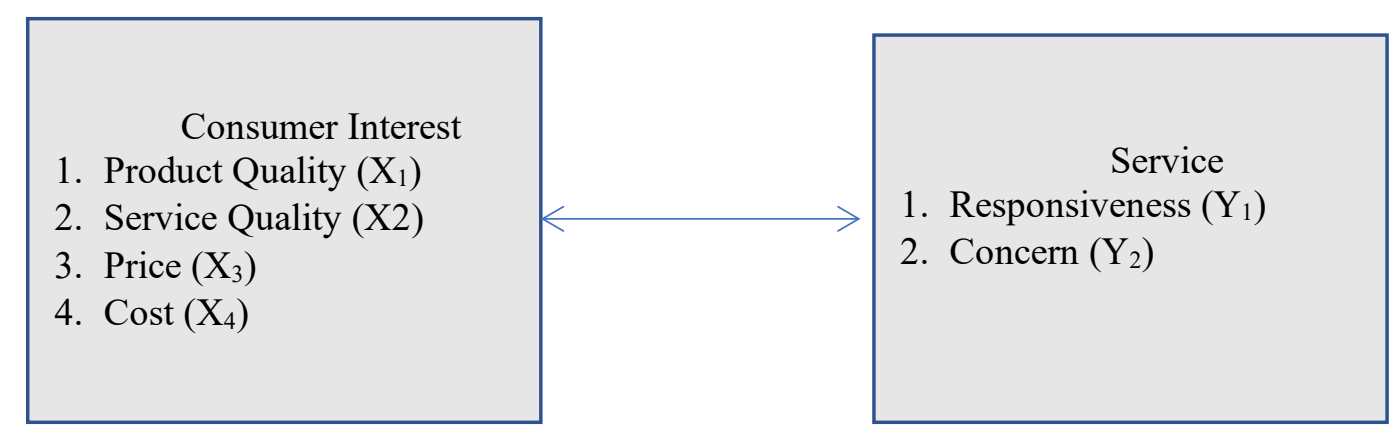

Figure 1: Conceptual Scheme

\subsection{RESEARCH HYPOTHESIS}

Based on the problem formulation that has been described above, it is suggested that there is a simultaneous relationship between elements of customer interest (product quality, service quality, price, and cost) in meeting service needs (responsiveness, care) of SMEs assisted by Klibi Tebing Tinggi in canonical analysis.

\subsection{OPERATIONAL DEFINITION OF RESEARCH VARIABLES}

In this study, there are six types of variables. However, as previously explained, in the canonical analysis there is no difference in the types of variables. The variable of consumer interest $(\mathrm{X})$ consists of Product Quality $\left(\mathrm{X}_{1}\right)$, Service Quality $\left(\mathrm{X}_{2}\right)$, Price $\left(\mathrm{X}_{3}\right)$, Cost $\left(\mathrm{X}_{4}\right)$ and Service $(\mathrm{Y})$ namely Responsiveness $\left(\mathrm{Y}_{1}\right)$, Concern $\left(\mathrm{Y}_{2}\right)$. 
Service Implementation of Consumer Interest in Tebing Tinggi Business Clinic Sumatera Utara

\section{RESULTS AND DISCUSSIONS}

\subsection{RESEARCH LOCATION}

The location of the research taken in this study is the consumers of UMKM assisted by KLIBI which are spread throughout the Tebing Tinggi City area. Researchers also took secondary data regarding an overview of the location of the Tebing Tinggi City Trade Office, which is located on Jl. Gunung Leuser No.1 Tebing Tinggi.

\subsection{POPULATION AND SAMPLE}

Population consisting of objects / subjects that have certain qualities and characteristics that are determined and then draw conclusions. The population taken for consumers from SMEs assisted by KLIBI Tebing Tinggi is 200 loyal consumers of assisted MSMEs starting from 2013 to 2017 productively. Sample selection is done by purposive sampling where the researcher determines certain characteristics that are considered to have a relationship with the population. Researchers chose a sample of consumers based on the activeness of consumers who were classified as loyal and interested in service and understood the marketing concept of SMEs assisted by Klibi Tebing Tinggi so that the researchers determined 100 consumers.

\subsection{TYPES AND SOURCES OF DATA}

Sources of data in this study were conducted using primary data and secondary data. Primary data sourced from research respondents were obtained based on the results of questionnaires and interviews related to elements of customer interest and fulfillment of customer service needs, while secondary data was obtained regarding the general description and results of library studies which were used to support relevant theories.

\subsection{TECHNICAL DATA ANALYSIS}

Canonical correlation analysis is a multivariate model that studies the relationship between a set of dependent variables and a set of independent variables. The data characteristics for canonical correlation are metric data, namely interval or ratio data. In the linear combination that has the largest correlation, a linear combination pair with the largest correlation value will be sought among all uncorrelated pairs. The general form of the canonical function is as follows:

$$
\mathrm{Y} 1+\mathrm{Y} 2=\mathrm{X} 1+\mathrm{X} 2+\mathrm{X} 3+\mathrm{X} 4
$$

(dependent variable metric set) (independent variable metric set)

So that it can be simplified:

$$
\text { Responsiveness + Concern = Product Quality + Service Quality + Price + Service }
$$

\subsection{BASIC ASSUMPTIONS OF CANONICAL CORRELATION TEST}

Canonical correlation is a multivariate model that examines the relationship between a set of dependent variables and a set of independent variables. Therefore, it is the same as other multivariate models, it is necessary to test the data. Testing the canonical correlation assumption that must be done is:

1) Outlier Test

2) Multivariate Normality Test

3) Linerity Test

\subsection{CANONICAL CORRELATION MODEL TEST}

The purpose of testing this canonical correlation model is to ensure that the results obtained are accurate. This test is done by:

1) Dimension Reduction Analysis

International Journal of Research -GRANTHAALAYAH 
2) Eigenvalue and Canonical Correlation

3) Multivariate Test of Significance

\subsection{OVERVIEW OF TEBING TINGGI BUSINESS CLINIC}

Tebing Tinggi Business Clinic (KLIBI) is as one of the barometers of entrepreneurial development in Tebing Tinggi is a solution for all MSMEs in Tebing City who have problems in increasing entrepreneurship. In developing the Tebing Tinggi economy, it takes a unity between the MSMEs and the government and other external parties to be able to market products to other areas, both Tebing Tinggi and outside Tebing Tinggi. KLIBI is a formation initiated by the Mayor of Tebing Tinggi Mr. Ir. Umar Zein Hasibuan, MM, for the next, a collaboration was formed between the Tebing Tinggi Kouperindag Agency and the Faculty of Economics and Business, University of Sumatra. With the existence of KLIBI, it is hoped that it will be able to provide a new repertoire in product nuances, packaging, marketing and the creation of an online trading concept that focuses on the superior products of Tebing Tinggi. The inauguration of KLIBI Tebing Tinggi was carried out at Balai Kartini Building on October 23rd, 2014 which was directly carried out by the Mayor of Tebing Tinggi as well as several motivations by several other community leaders. On this occasion, a Memorandum of Understanding (MOU) was held between the Mayor of Tebing Tinggi as the City Government of Tebing Tinggi and the KLIBI Tebing Tinggi consultant and supervision team represented by the Dean of the Faculty of Economics and Business, University of North Sumatra, Prof. Dr. Azhar Maksum. Thus KLIBI Tebing Tinggi is a solution to entrepreneurship that occurs in Tebing Tinggi City. For the future time, business supervision will be carried out for all who are members of KLIBI Tebing Tinggi.

Programs and activities that will be carried out by KLIBI are strived to develop its members through training for MSEs who are members of KLIBI such as Business Training both in all modern aspects so that later they will visit culinary tours in other cities to see, feel and assess how all marketing concepts are made in the city so that it can provide inspiration to increase business innovation. Partnership patterns will be formed through collaborative activities between entrepreneurs who have been successful in doing business and also other entrepreneurs who want to collaborate with entrepreneurs in Tebing Tinggi City. To improve the quality of MSMEs, KLIBI certainly needs to improve how KLIBI partners' services to services with consumers to achieve optimal results of business continuity.

\subsection{RESULTS OF CANONICAL DATA INTERPRETATION}

Because there are two dependent variables and four independent variables, if the smallest number is taken, it is the number two. Thus, two Canonical Functions will be formed

Eigenvalues and Canonical Correlations

Root No. Eigenvalue Pct. Cum. Pct. Canon Cor. Sq. Cast

$1 \quad 60.8766399 .5903099 .59030 .99189 \quad 98384$

$2 \quad 25043.40970100 .00000 .44752 \quad .20028$

Dimension Reduction Analysis

Roots Wilks L. F Hypoth. DF Error DF Sig. of F

1 T0 $2.01292183,210138.00188 .00 \quad .000$

2 TO $2.799727 .930443 .0095 .00 \quad .000$ 
Service Implementation of Consumer Interest in Tebing Tinggi Business Clinic Sumatera Utara

Two Canonical Functions are shown in the Root No section, with the canonical correlation number (CANON COR) for Function 1 being 0.98384 and Function 2 being 0.2028 . When seen in the Sig. of F, which tests the significance of CANONICAL FUNCTION, it can be seen that Function 1 and 2 have a significant number of 0.000 .

From these results, it can be seen that the number of significance functions 1 and 2 is below 0.05 , so it is simultaneously considered unable to be processed further.

Multivariate Tests of Significance $(S=2, M=1 / 2, N=46)$

Test Name Value Approx. F Hypoth. DF Error DF Sig. of F

Pillais $\quad \begin{array}{lllll}1.18412 & 34.46914 & 8.00 & 190.00 & 0\end{array} 000$

Hotellings $\quad 61.12707710 .602188 .00186 .00 \quad .000$

Wilks. $01292 \quad 183,210138.00188 .00 \quad .000$

Roys $\quad .98384$

Note .. F statistics for WILKS 'Lambda is exact.

Meanwhile, if tested together with the test name: Pillais, Hotellings and Wilks for the Sig. of F for all three procedures are below 0.05 which is 0.00 . Thus, if combined together, the canonical function 1 and canonical function 2 are significant and can be processed further.

There is a difference between individual and collective (collective) testing. For that, you can see the CANONICAL CORRELATION figures in the Eigenvalues and Canonical Correlations table, with the numbers:

1) CANONICAL CORRELATION function 1 is 0.98384

2) CANONICAL CORRELATION function 2 is 0.20028

In the limit of 0.5 for the correlation strength of two variables, function 2 has a low canonical correlation number, so it can be issued for further analysis. Thus, only function 1 will be analyzed further, because besides being significant individually and collectively, it also has a high canonical correlation number.

\subsection{DISCUSSION}

A collection of several variables (Canonical variates) that form a variate where in this case the dependent variate is $\mathrm{Y}_{1}$ : Responsiveness, $\mathrm{Y}_{2}$ : Concern, and independent which has $\mathrm{X}_{1}$ : Product Quality, $\mathrm{X}_{2}$ : Service Quality, $\mathrm{X}_{3}$ : Price and $\mathrm{X}_{4}$ : Cost. There are two ways to measure canonical variates:

\section{Canonical Wights}

Correlations between DEPENDENT and canonical variables

Function No.

Variable 12

Y1 $1.00000-.00091$

Y2 .70125.71291

Variance in dependent variables explained by canonical variables

CAN. VAR. Pct Var DEP Cum Pct DEP Pct Var COV Cum Pct COV

174.5877774 .5877773 .3823473 .38234

International Journal of Research -GRANTHAALAYAH 
Raw canonical coefficients for COVARIATES

Function No.

COVARIATE 1

$\begin{array}{lll}\mathrm{X} 1 & -.73910 & 6,03549 \\ \mathrm{X} 2 & .32368 & .47426 \\ \mathrm{X} 3 & -.97103 & -1.42279 \\ \mathrm{X} 4 & 1.68111 & -5.93822\end{array}$

By not paying attention to function 2 (the second column of numbers), you can see a row of correlation numbers between each variable and its variables. For the dependent variable, the two correlation numbers are equally high, because it is above 0.5 , namely 1 and 0.70125 . Whereas for the independent variable (covariates), the correlation number above 0.5 is $\mathrm{X} 4$ : Cost

\section{Canonical Loadings}

Y1 $1.00000-.00091$

Y2 .70125.71291

Variance in dependent variables explained by canonical variables

CAN. VAR. Pct Var DEP Cum Pct DEP Pct Var COV Cum Pct COV

$1 \quad 74.5877774 .5877773 .3823473 .38234$

$2 \quad 25.41223100 .000005 .0895278 .47186$

Raw canonical coefficients for COVARIATES

Function No.

COVARIATE 12

$\begin{array}{lll}\mathrm{X} 1 & -.73910 & 6,03549 \\ \mathrm{X} 2 & .32368 & .47426 \\ \mathrm{X} 3 & -.97103 & -1.42279 \\ \mathrm{X} 4 & 1.68111 & -5.93822\end{array}$

Without paying attention to function 2 (the second column of numbers), you can see a row of canonical loadings between each variable and its variable (function). For the dependent variable, the two canonical loadings numbers are the same, because above 0.5, namely 1 and 0,70125 . For independent variables (covariates), the correlation numbers above 0.5 are all that is X4: Cost.

\section{CONCLUSIONS AND RECOMMENDATIONS}

From the output of canonical weight or canonical loading, it can be said: 
Service Implementation of Consumer Interest in Tebing Tinggi Business Clinic Sumatera Utara

1) There is a significant and significantly correlated relationship between the dependent variates, namely responsiveness and care with the independent variate variables, namely product quality, service quality, price and cost.

2) However, of the 4 independent variables, there is only one variable that has the closest relationship, namely cost

3) A positive sign on the cost variable indicates that the consumers of Klibi Tebing Tinggi's MSMEs are very familiar with Klibi Tebing Tinggi's MSME products because the affordable costs to buy thus strengthen the responsiveness and concern of consumers to buy products.

MSMEs assisted by the Tebing Tinggi Business Clinic need to consider:

1) Product Quality, Service Quality and Competitive Prices to improve the quality of products and develop into digital business

2) The Tebing Tinggi City Government needs to improve the quality of product endorsement among Tebing Tinggi and Indonesian consumers by increasing business promotion and international exhibitions

3) Entrepreneurship training needs to be done to increase the mindset of a business that is out of the box on a regular basis

4) For the next researcher can improve the quality of research by adding variables and research models.

\section{SOURCES OF FUNDING}

This research received no specific grant from any funding agency in the public, commercial, or not-for-profit sectors.

\section{CONFLICT OF INTEREST}

The author have declared that no competing interests exist.

\section{ACKNOWLEDGMENT}

This research is the output of a novice lecturer research grant with a research contract for 2020 Fiscal Year between North Sumatra region I higher education service institutions and Universitas Al Azhar Number: 250 / LL1 / PG / 2020 and a Research Contract for the 2020 Fiscal Year between the Institute for Research and Community Service, Universitas Al Azhar and researchers for the 2020 Fiscal Year Number: 02 / UA / LPPM / P / VII / 2020.

\section{REFERENCES}

[1] Z. S. Putra, Giardo Permadi; Arifin, "Pengaruh Kualitas Produk Terhadap Keputusan Pembelian Dan Dampaknya Terhadap Kepuasan Konsumen (Survei Pada Mahasiswa Administrasi Bisnis Fakultas Ilmu Administrasi Angkatan 2013 Dan 2014 Universitas Brawijaya Yang Melakukan Pembelian Paket Data Kampus )," Vol. 48, No. 1, Pp. 124-131, 2017.

[2] I. N. Nurcaya, Kadek Indri Novita Sari Putri, "Pengaruh Dimensi Kualitas Pelayanan Jasa Terhadap Kepuasan Pelanggan D \& I Skin Centre Denpasar Fakultas Ekonomi Universitas Udayana, (Unud) Bali” Pp. 918-937, 2011.

[3] Https://Tebingtinggikota.Bps.Go.Id/, “No Title," Sosial Kependudukan, 2017.

[4] H. D. M. Herawati, "Pengaruh Kualitas Bahan Baku Dan Proses Produksi Terhadap Kualitas Produk Pada Ud. Tahu Rosydi Puspan Maron Probolinggo," Pros. Semin. Nas., Pp. 463-482, 2017.

[5] Putra, M. Umar Maya, “Konsep Pengembangan Ekonomi Kerakyatan Di Kota Medan,” Vol. 5, No. April, Pp. 19, 2015.

[6] Putra, M. Umar Maya And A. Dilham, “Kecamatan Dumai Timur (Studi Kasus : Kelurahan Bukit Timah )," Vol. 7, No. April, Pp. 1-8, 2017. 
[7] M. Shabastian, H. Samuel, J. M. Pemasaran, U. K. Petra, And J. Siwalankerto, "Pengaruh Strategi Harga Dan Strategi Produk Terhadap Brand Loyalty Di Tator Café Surabaya Town Square,” J. Manaj. Pemasaaran, Vol. 1, No. 1, Pp. 1-9, 2013.

[8] K. Sarini, "Harga, Kualitas Produk Dan Kualitas Pelayanan Pengaruhnya Terhadap Keputusan Pembelian Mobil Toyota Avanza," J. Emba Issn 2303-1174, Vol. 1 No. 3, No. 3, Pp. 1251-1259, 2013.

[9] M. Jannah, “Analisis Pengaruh Biaya Produksi Dan Tingkat Penjualan Terhadap Laba Kotor,” J. Banq., Vol. 4, No. 1, Pp. 87-112, 2018.

[10] J. Pratiwi, "Penerapan Biaya Standar Dalam Pengendalian Biaya Produksi Pada Pt. Pertani (Persero) Cabang Sulawesi Utara," J. Emba, Vol. 1, No. 4, Pp. 1617-1626, 2013.

[11] A. S. S. Y. A. Yafie, "Kepuasan Pelanggan (Studiapadafpelanggan Food And Beverage 8 Oz Coffee Studio Malang )," J. Adm. Bisnis, Vol. 35, No. 2, Pp. 11-19, 2016.

[12] P. Syarifah, Tengku., Putra, M. Umar Maya, "Motivation and Entrepreneurs Training for Tinggi Raja Society of Asahan Regency," In 2nd Annual International Seminar on Transformative Education and Educational Leadership (Aisteel 2017) Motivation, 2017, Vol. 104, No. Aisteel, Pp. 1-5.

[13] Dilham, Ami., Putra, M. Umar Maya., \& Parimin. Social Economic Community Mapping Around Binjai Utara (Case Study: The People in Tandem Hilir). Proceedings of the 1st Annual International Seminar On Transformative Education And Educational Leadership (AISTEEL) E-ISSN: 2648-4613, 600-607, 2016.

[14] A. Dilham And Putra, M. Umar Maya, "Social Economic Community Mapping Around Binjai Utara (Case Study: The People In Tandem Hilir )," In Proceedings Of The 1st Annual International Seminar On Transformative Education And Educational Leadership (Aisteel) E-Issn: 2548-4613, 2016, No. Ii, Pp. 600-607. 